\title{
Edukasi Pengelolaan Obat Melalui DAGUSIBU untuk Mencapai Keluarga Sadar Obat
}

\author{
Wahida Hajrin ${ }^{*}$, Candra Dwipayana Hamdin"1, Dyke Gita Wirasisya ${ }^{1}$, Gusti Ayu Putu Sri \\ Erwinayanti ${ }^{1}$, Raisya Hasina ${ }^{1}$ \\ ${ }^{1}$ Program Studi Farmasi, Fakultas Kedokteran, Universitas Mataram, Mataram, Indonesia
}

\author{
Article Info \\ Received : 12-03-2020 \\ Revised : 02-04-2020 \\ Accepted: 10-04-2020
}

\begin{abstract}
The high ratio of population in Pamenang, Tanjung, and Gangga sub-districts compared to existing facilities and health workers is a very principle problem related to health education for the community, including information about medicine. One of whichis about the correct methods of how to get, use, save, and dispose medicines which is abbreviated with the DAGUSIBU program, including how to use special medicines. The aim of this socialization was to educate the patients in the public health center in Pemenang, Tanjung, and Gangga sub-districts about DAGUSIBU. The DAGUSIBU socialization program was carried out through the delivery of material, discussions, questions and answers, and demonstration by the audience and Pharmacists. Participants that incidentally were patients in public health centrewere very enthusiastic about this program as evidenced by the activeness of the participants in asking questions and answering questions about DAGUSIBU.
\end{abstract}

Keywords: DAGUSIBU, socialization, Pemenang, Tanjung, Gangga, medicine

Citation: Hajrin, W., Hamdin, C.D., Wirasisya, D.G., Erwinayanti, G.A.P.S., \& Hasina, R. (2020). Edukasi pengelolaan obat melalui DAGUSIBU untuk mencapai keluarga sadar obat. INDRA Jurnal Pengabdian kepada Masyarakat, 1(1), 5-7.

\section{Pendahuluan}

DAGUSIBU merupakan singkatan dari "DApat, GUnakan, SImpan, BUang" obat dengan benar. DAGUSIBU adalah jargon kampanye program Gerakan Nasional Keluarga Sadar Obat yang merupakan salah satu hal yang paling mendasar di bidang farmasi. Dalam pengobatan sendiri sebaiknya mengikuti persyaratan penggunaan obat rasional (Kemenkes RI, 2011). Untuk mewujudkan penggunaan obat rasional, masyarakat harus mengetahui cara mendapatkan, menggunakan, menyimpan, dan membuang obat dengan benar sehingga terwujud peningkatan derajat kesehatan masyarakat.

Kabupaten Lombok Utara (KLU) merupakan salah satu daerah di Nusa Tenggara Barat yang memiliki masalah kesehatan yang signifikan meliputi kurangnya sarana dan prasarana kesehatan. Kabupaten Lombok
Utara hanya memiliki 1 Rumah Sakit Umum Daerah, 1 klinik swasta, dan 3 apotek. Jumlah tenaga kesehatan yang menunjang pelayanan kesehatan juga terbilang minimal dibanding jumlah penduduk. Sarana kesehatan yang ada di masing-masing kecamatan yaitu puskesmas dengan 1 Puskesmas Pembantu. Permasalahanpermasalahan tersebut menyebabkan kurangnya informasi yang diperoleh masyarakat terkait kesehatan, pengobatan dan cara menggunakan obat. Selain itu, sebanyak 57\% masyarakat KLU bekerja pada sektor pertanian dan peternakan. Hal ini menjadi salah satu alasan penyuluhan kesehatan sangat dibutuhkan oleh masyarakat setempat (Dinas DUKCAPIL, 2012).

Berdasarkan latar belakang tersebut, perlu dilakukan sosialisasi DAGUSIBU untuk memenuhi kebutuhan masyarakat akan informasi kesehatan dan pengobatan. DAGUSIBU merupakan salah satu solusi untuk meningkatkan pemahaman masyarakat akan obat 
dan pengobatan dalam menghadapi permasalahan kesehatan sehari-hari, untuk menunjang terwujudnya peningkatan derajat kesehatan masyarakat.

\section{Metode}

Kegiatan sosialisasi DAGUSIBU dilakukan di 3 Puskesmas, yaitu Puskesmas Pemenang, Puskesmas Tanjung, dan Puskesmas Gangga. Peserta sosialisasi adalah pengunjung masing-masing puskesmas. Sosialisasi dilakukan dengan penyampaian materi oleh Apoteker dan dilanjutkan dengan sesi tanya jawab oleh audiensi sekaligus peragaan DAGUSIBU oleh Apoteker. Penyampaian materi dilakukan secara interaktif menggunakan media power point dan menggunakan video sehingga lebih menarik dan interaktif. Selain itu juga disiapkan game (permainan) terkait materi untuk peserta disertai hadiah menarik untuk pemenang game. Dalam penyampaian juga disertai contoh dengan alat peraga untuk cara penggunaan obat khusus seperti penggunaan obat mata dan obat telinga yang benar, penggunaan inhaler yang tepat serta cara membuang obat berupa tablet ataupun sirup yang benar.

\section{Hasil dan Pembahasan}

Pelaksanaan kegiatan sosialisasi mengalami beberapa kali penyesuaian karena terjadi perubahan jumlah dana operasional. Rencana sosialisasi yang semula dilaksanakan selama tiga hari dengan jadwal sehari satu kecamatan dipadatkan menjadi dua hari namun tetap mencakup tiga kecamatan sesuai rencana, yaitu Pemenang, Tanjung, dan Gangga. Tiga kecamatan yang dimaksud mengambil sasaran pasien yang berkunjung pada puskesmas di masing-masing kecamatan.

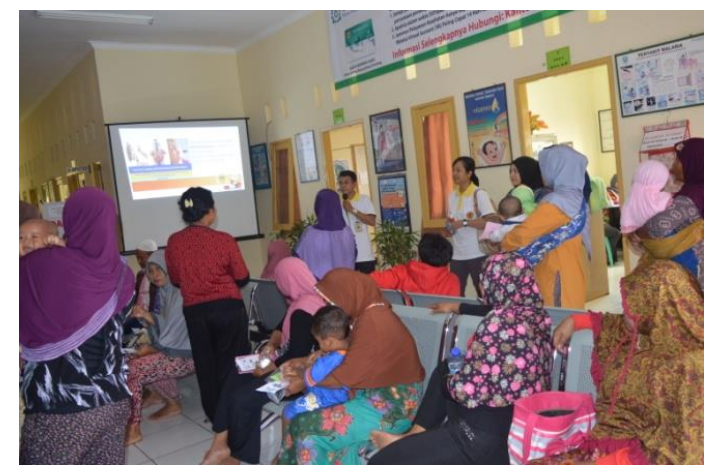

Gambar 1. Pelaksanaan sosialisasi DAGUSIBU di Puskesmas Gangga

Puskesmas Gangga merupakan tempat sosialisasi hari pertama. Sosialisasi dilaksanakan tepat jam 9 pagi di saat puskesmas sedang penuh dengan pengunjung yang berobat. Tim membagi diri menjadi penyuluh dengan tugas memberi penyuluhan dan mendemonstrasikan cara pemakaian obat yang baik dan benar, tenaga administrasi yang bertugas mendata pasien yang mengikuti penyuluhan dan memberi snack serta selebaran yang berisi informasi tentang DAGUSIBU, petugas dokumentasi yang bertugas mendokumentasikan acara dari awal hingga akhir. Sosialisasi hari pertama dibantu oleh tim dari Rumah Sakit Umum Daerah dan Dinas Kesehatan Lombok Utara. Dari awal hingga akhir, kegiatan berjalan relatif lancar dengan beberapa kendala yang dapat diatasi. Pelaksanaan kegiatan di puskesmas Gangga dapat dilihat pada Gambar 1.

Hari kedua sosialisasi dilaksanakan di Puskesmas Tanjung dan Puskesmas Pemenang. Sosialisasi di Puskesmas Tanjung dilakukan pada jam 9 pagi hari di area tunggu pasien. Bentuk area yang memanjang, sempit, dan agak gelap menyebabkan pelaksanaan di Puskesmas Tanjung cenderung tidak seramai di Puskesmas Gangga. Namun, antusiasme peserta lebih tinggi dari hari sebelumnya. Pasien di Puskesmas Tanjung lebih banyak mengutarakan pertanyaan dan pendapat dibanding para peserta dari Puskesmas Gangga, termasuk dokter jaga yang bertanya tentang masalah DAGUSIBU kepada tim sosialisasi. Kegiatan sosialisasi di Puskesmas Tanjung dapat dilihat pada gambar 2 .

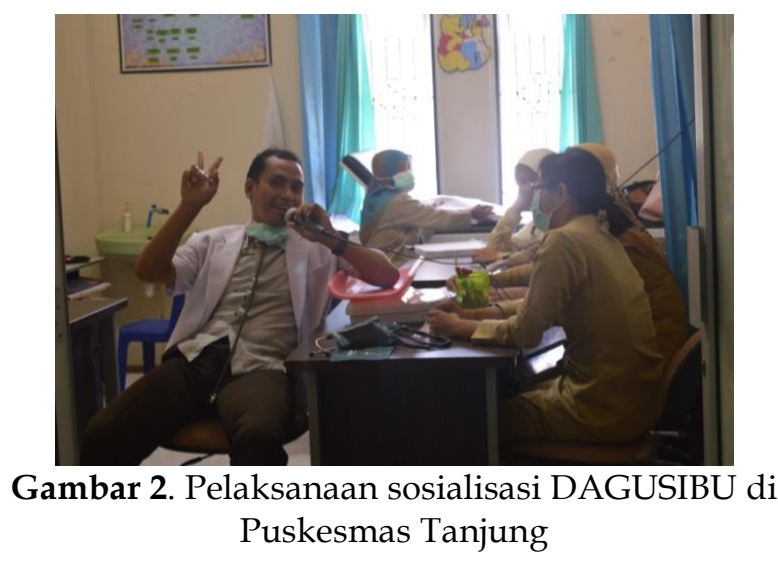

Pelaksanaan kegiatan di Puskesmas Pemenang dilakukan pada pukul 10.30 sehingga pengunjung puskesmas sudah sepi. Untuk mengoptimalkan kegiatan, tim DAGUSIBU menyebar untuk memberikan informasi pada para pasien di lingkungan Puskesmas Pemenang yang sebagian masih menunggu pengambilan obat dan menunggu pasien rawat inap. Kegiatan sosialisasi di Puskesmas Pemenang dapat dilihat pada gambar 3 .

Materi sosialisasi yang disampaikan adalah cara mendapatkan obat yang sesuai dengan keluhan dan penyakit, cara memperoleh obat di tempat yang tepat, cara dan waktu menggunakan obat yang tepat sesuai dengan instruksi, cara menyimpan obat yang baik dan benar sesuai jenis sediaan serta cara membuang obat 
yang sudah kadaluarsa dengan benar. Sosialisasi DAGUSIBU diharapkan dapat menciptakan keluarga sadar obat dan peningkatan pemahaman tentang pengelolaan obat dengan benar (Yati, Hariyanti, Dwitiyanti, \& Lestari, 2018; Suryoputri \& Sunarto, 2019; Zulkarni, Afrianti, \& Maqfira, 2019; Futri \& Vera, 2020).

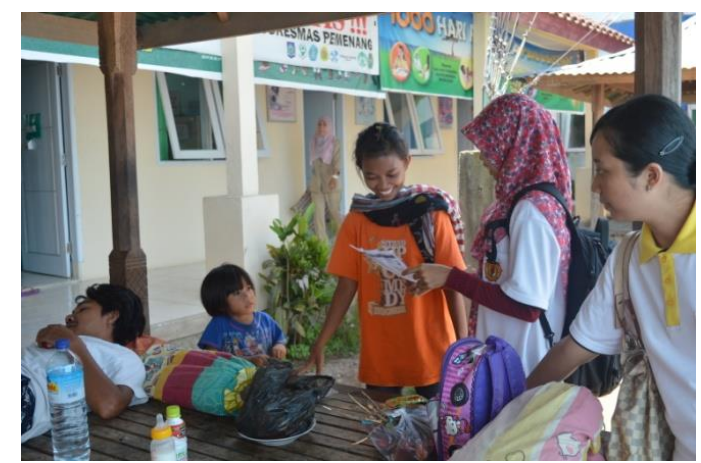

Gambar 3. Pelaksanaan sosialisasi DAGUSIBU di Puskesmas Pemenang

Beberapa kendala yang dihadapi dalam pelaksanaan kegiatan adalah waktu pelaksanaan kegiatan yang singkat terutama pada hari kedua, menyebabkan keterbatasan jumlah peserta sosialisasi. Selain itu, sosialisasi memakai jam aktif berobat menyebabkan banyak interferensi yang terjadi, seperti perhatian pasien yang terbagi karena mendengarkan panggilan nomor antrean puskesmas untuk berobat, tempat yang kurang luas untuk sosialisasi tidak sebanding dengan jumlah pasien sehingga suasana menjadi ramai dan kurang kondusif. Namun, jam aktif berobat memiliki kelebihan terkait kemudahan dalam mengumpulkan peserta sehingga info dari sosialisasi diharapkan bisa meluas.

Beberapa perubahan perlu dilakukan dalam meningkatkan pemahaman peserta terkait DAGUSIBU. Selain waktu yang lebih intens, diperlukan pula metode lain yang lebih efektif. Salah satunya adalah dengan pembentukan kader yang nantinya dapat membantu masyarakat sekitar dalam penerapan DAGUSIBU, misalnya melalui metode CBIA (Cara Belajar Ibu Aktif) (Djuria, 2018).

\section{Simpulan}

Dari kegiatan pengabdian yang dilakukan dapat disimpulkan bahwa masyarakat mulai mengerti dan memahami cara-cara mendapatkan, menggunakan, menyimpan dan membuang obat dengan baik dan benar. Apabila akan dilaksanakan kegiatan pengabdian selanjutnya disarankan alokasi waktu satu hari hanya untuk satu tempat pengabdian untuk memaksimalkan pasien pada puskesmas tujuan sosialisasi.

\section{Daftar Pustaka}

Dinas DUKCAPIL. (2012). Data Pekerjaan Masyarakat Kabupaten Lombok Utara. Nusa Tenggara Barat.

Djuria, R. F. (2018). Peningkatan pengetahuan tentang DAGUSIBU terhadap kader Gerakan keluarga sadar obat (GKSO) desa Tanjung Gunung Bangka Tengah. Jurnal Kesehatan Poltekkes Pangkalpinang, 6(1), 33-38.

Futri, C. L., \& Vera, Y. (2020). Penyuluhan cara penyimpanan obat yang baik dan benar di desa Labuhan Labo. Jurnal Education and Development, 8(1), 1-3.

Kemenkes RI. (2011). Modul Penggunaan Obat Rasional. Jakarta: Kementerian Kesehatan Republik Indonesia.

Suryoputri, M. W., \& Sunarto, A. M. (2019). Pengaruh edukasi dan simulasi DAGUSIBU obat terhadap peningkatan keluarga sadar obat di desa Kedungbanteng Banyumas. Jurnal Aplikasi Teknik dan Pengabdian Masyarakat, 3(1), 51-55.

Yati, K., Hariyanti, Dwitiyanti, \& Lestari, P. M. (2018). Pelatihan pengelolaan obat yang tepat dan benar di UKS sekolah-sekolah Muhammadiyah wilayah DKI Jakarta. Jurnal SOLMA, 7(1), 42-49.

Zulkarni, R., Afrianti, R., \& Maqfira, P. (2019). Gambaran pengetahuan keluarga dalam mendapatkan dan menggunakan obat antibiotik di kecamatan Lima Kaum kabupaten Tanah Datar. Jurnal Sains Farmasi dan Klinis, 6(1), 63-68. 